\title{
A NEW SPECIES OF CATASETUM (ORCHIDACEAE: CATASETINAE) FROM CASANARE, COLOMBIA
}

\author{
Miguel M. Bonilla Morales ${ }^{1}$, Johan de J. Mosquera Hernández ${ }^{1}$ \\ \& Adarilda Petini-Benell2 ${ }^{2,3}$
}
${ }^{1}$ Grupo de investigación EduciTec, Lic. Pdn Agropecuaria, Universidad de los Llanos, Sede Barcelona, Villavicencio, Colombia
${ }^{2}$ Post-Graduate Program in Ecology and Conservation of the Biodiversity, Universidade Federal de Mato Grosso. Av. Fernando Correa da Costa, 2.367, Bairro Boa Esperança, CCBS-II, 78060-900 Cuiabá, Mato Grosso State, Brazil
${ }^{3}$ Author for correspondence: ada.benelli@gmail.com

\begin{abstract}
A new species of Catasetum was found in eastern Colombia, Casanare Department, in the Orinoquía bioregion. The species is described and illustrated, and data associated with its phenology, distribution and conservation status are discussed. The new species, $C$. lucisuareziae, is related to other species found in the same region, like $C$. rectangulare and $C$. callosum, from which it mainly differs by the three-lobed labellum and the presence of two subglobular calli at the base.
\end{abstract}

Resumen. Una nueva especie de Catasetum fue encontrada en el departamento de Casanare hacia el oriente de Colombia, en la bioregión de la Orinoquía. Se describe e ilustra la especie y se estipulan parámetros asociados a su fenología, distribución y estado de conservación. La nueva especie, Catasetum lucisuareziae, es comparable con otras especies que se encuentran en la misma región, como C. rectangulare y C. callosum, pero difiere de ellas principalmente por su labelo trilobulado y la presencia de dos callos subglobulares en la base.

Key words / Palabras clave: biodiversidad, biodiversity, Catasetum bicolor, Catasetum lucisuareziae, conservación, conservation, Cymbidieae, Epidendroideae, Orinoquía

Introduction. Orchidaceae include about 28,000 species and, together with Asteraceae, it is the most diverse group of angiosperms (Chase et al. 2015). Colombia is one of the countries with the greatest diversity of Orchidaceae, with 4,270 species in 270 genera; about $35 \%$ of the species are endemic (Betancourt, Sarmiento, Toro-González \& Valencia 2015). Most of the endemic species are native to the Andean bioregion. The areas with the lowest diversity are the Orinoco river basin and the Atlantic slopes, with only 143 species recorded (Betancourt et al. 2015, Sarmiento 2007).

The genus Catasetum includes about 140 species distributed throughout the Neotropics (Romero \& Jenny 1993, Romero 2012), although Chase et al. (2015) accept up to 176 taxa. For Colombia, Ortiz and Uribe (2007, 2014), Bonilla, Mosquera and Otero (2013a), Ortiz (2015) and Betancourt et al. (2015) recognize 37 species.

Materials and methods. Casanare is one of the least studied departments of Colombia (Usma \& Trujillo
2011). In the Orchidaceae, 32 genera and 58 species have been recorded from this area (Betancourt et al. 2015). However, recent studies conducted in the Orinoco river basin addressed the importance of the region's biodiversity, showing that 77 orchid species were recorded in the Meta Department alone (Jiménez 2011). Two years after the start of the explorations in this region, the number of documented orchid species already overcome the 300 taxa (Bonilla et al. 2013b).

The material examined for this study was collected in 2013, during the exploration of Casanare, when a population of a unidentfied species of Catasetum was found in the town of Hato Corozal. The plants were cultivated in a greenhouse at Villavicencio (Meta), in the farm of Luci Suárez, for their documentation and study.

Results. Based on floral morphology, the new species described hereafter, Catasetum lucisuareziae, belongs to a small group of species that in Colombia includes $C$. bicolor Klotzsch, C. callosum Lindl. and C. rectangulare G.F.Carr. 
Key to the Colombian species of CATASEtum Related to C. LuCisuareziaE

1. Petals linear to oblong-lanceolate

2. Lateral sepals falcate, labellum rectangular

C. rectangulare

2'. Lateral sepals reflexed or oblique, labellum lanceolate, ovate or trilobed

3. Labellum lanceolate, ovate or slightly off site with a central callus apiculate C. callosum

3'. Labellum trilobed, without a callus

C. boyi

1'. Petals elliptic or elliptic-lanceolate

\section{4}

4. Labellum trilobed, the mid-lobe slightly elliptic

C. lucisuareziae

4'. Labellum pentalobed, the mid-lobe triangular

C. bicolor

Catasetum lucisuareziae M. Bonilla, J. Mosquera \& Benelli, sp.nov. Fig. 1-2.

TYPE: Colombia. Casanare: Hato Corozal, Bosque de Sabana, 6.133541 ${ }^{\circ}-71.728464^{\circ}, 222$ m, 26-VI-2013, M Bonilla-M., J Mosquera, A Velázquez \& L Suárez, s.n. (holotype, LLANOS!).

Diagnosis: Catasetum lucisuareziae is similar to $C$. bicolor, from which it mainly differs by the 3-lobed labellum (vs. 5-lobed) and the two subglobular calli at the base of the lip (vs. two ligules); it also resembles C. rectangulare and C. callosum, from which it differs by the ovate-lanceolate bracts, elliptic petals, 3-lobed labellum with 2 basal subglobular calli, and erect staminal column.

Epiphytic, cespitose herb, 15-40 $\mathrm{cm}$ tall when leafy. Pseudobulb ca. $13 \times 6 \mathrm{~cm}$, terete, ellipticalspindle, of 1-9 internodes. Leaves ca. $25 \times 4 \mathrm{~cm}$, oblong-lanceolate, distichous, plicate, deciduous. Inflorescence basal, 1-2 symultaneous, manyflowered (12-20) racemes, straight or curved at the apex, ca. $25 \mathrm{~cm}$ long, provided with basal bracts. Male flowers resupinate, fragrant, brown, the labellum yellow-green. Pedicel ca. $45 \mathrm{~mm}$ long, including the short ovary. Floral bracts lanceolateovate, $9 \times 3 \mathrm{~mm}$. Dorsal sepal oblong-elliptic, acute, concave, membranous, ca. $29 \times 7 \mathrm{~mm}$. Lateral sepals elliptic, acute, convex, membranous, ca. $30 \times 7 \mathrm{~mm}$. Petals elliptic, convex, membranous, ca. $26 \times 5 \mathrm{~mm}$. Labellum 3-lobed, sacciform, cordate when spread, fleshy, 6-7 mm long, 10.0-10.8 mm wide, $9 \mathrm{~mm}$ deep, the lateral lobes elliptic with the margin sometimes undulate, the midlobe triangular, round, with two subglobular calli at the base. Column trigonous, erect, ca. $18 \mathrm{~mm}$ long, 3-4 mm wide toward the apex, yellowish-green stained brown; rostellum $6-8 \mathrm{~mm}$, slim and projected forward and backward. Anther operculate, apiculate, unilocular, ca. $9 \times 3 \mathrm{~mm}$, the apex yellowish-green. Pollinia 2, elliptic-obovate, flattened dorsiventrally, split, yellow, ca. $3 \times 1 \mathrm{~mm}$, on a oblong stipe and sticky viscidium. Female flowers not observed. Immature fruit green, trilocular.

Distribution: The species has been hiterto recorded only from the municipality of Hato Corozal (Fig. 3).

Eponymy: In honor of Luci Suárez, who has taken charge of the conservation and management of native orchid species of Meta.

Phenology: This species flowered in January in cultivation.

Conservation Status: According to the criteria of the IUCN (2014), C. lucisuareziae is characterized as Data Deficient (DD). The only known population of the species is not located within any conservation unit. However, ex situ conservation management performed by Mrs. Luci Suárez and his son on their farm is highly relevant for its preservation.

Catasetum lucisuareziae belongs to subgenus Catasetum section Isoceras (Mansf.) Senghas, characterized by symmetrical antennae (Senghas 1990, Romero 2009).

Among the species found in the bioregion of the Orinoco (Bonilla et al. 2014), the most alike are C. rectangulare and C. callosum. The three species can be easily distinct, however, on the basis of their characteristic floral morphology (Table 1). Catasetum rectangulare and C. callosum have linear and oblong-lanceolate floral bracts, respectively, while $C$. lucisuareziae has ovate-lanceolate bracts. While in $C$. lucisuareziae the petals are elliptic, they are linear to oblong-lanceolate in C. rectangulare and C. callosum. 

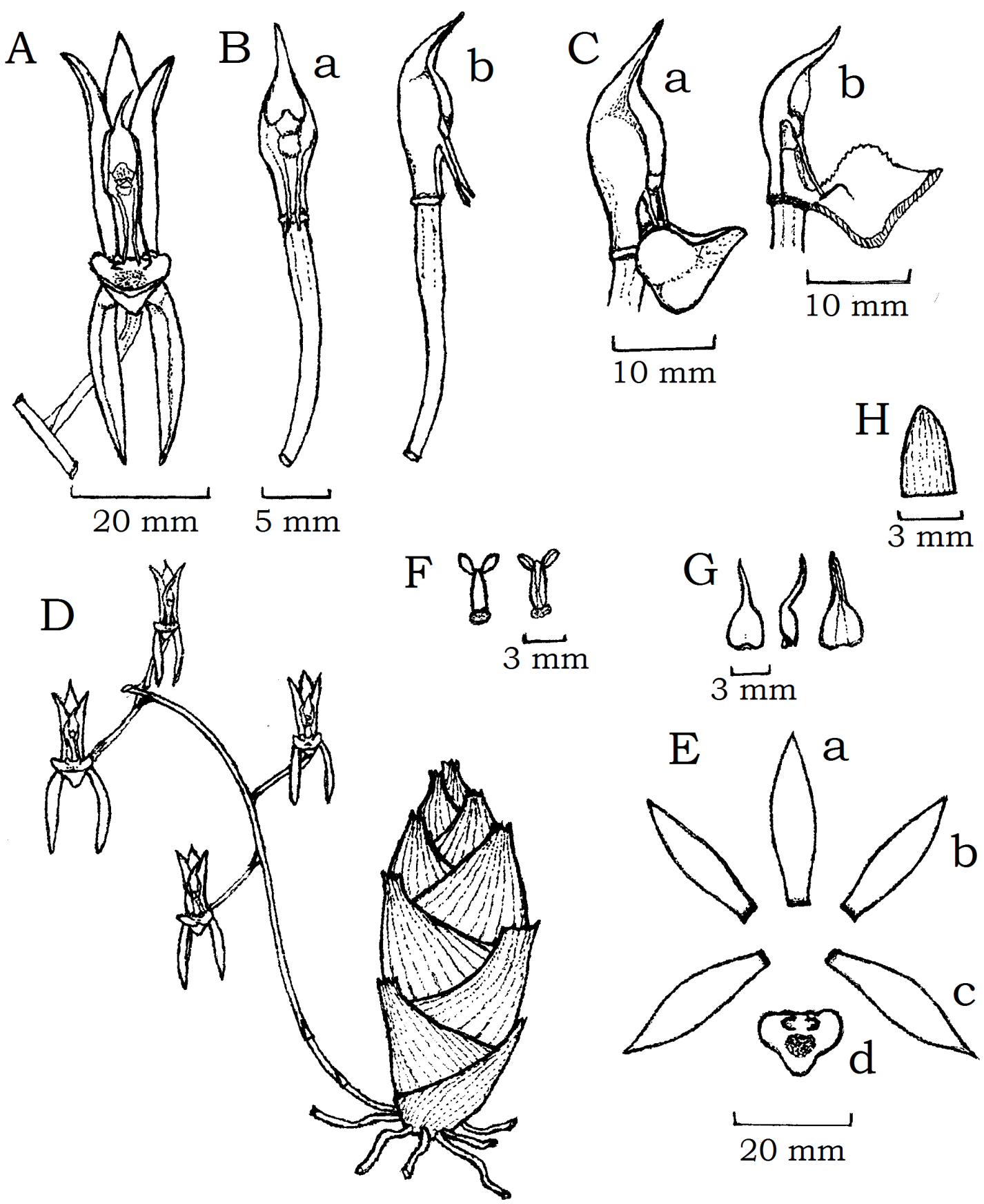

Figure 1. Catasetum lucisuareziae. A. Male flower, frontal view. B. Column set: a, frontal view; b, lateral view. C. Column with labellum set: a, lateral view; b, same, with the labellum longitudinally sectioned. D. General view of the plant habit without leaves, the inflorescence with male flowers. E. Male flower, dissected perianth: a, dorsal sepal; b, petal; c, lateral sepal; d, labellum, frontal view. F. Pollinarium, two views. G. Anther cap in frontal, lateral and dorsal views. H. Floral bract. Illustration by M. M. Bonilla-M. from the type. 


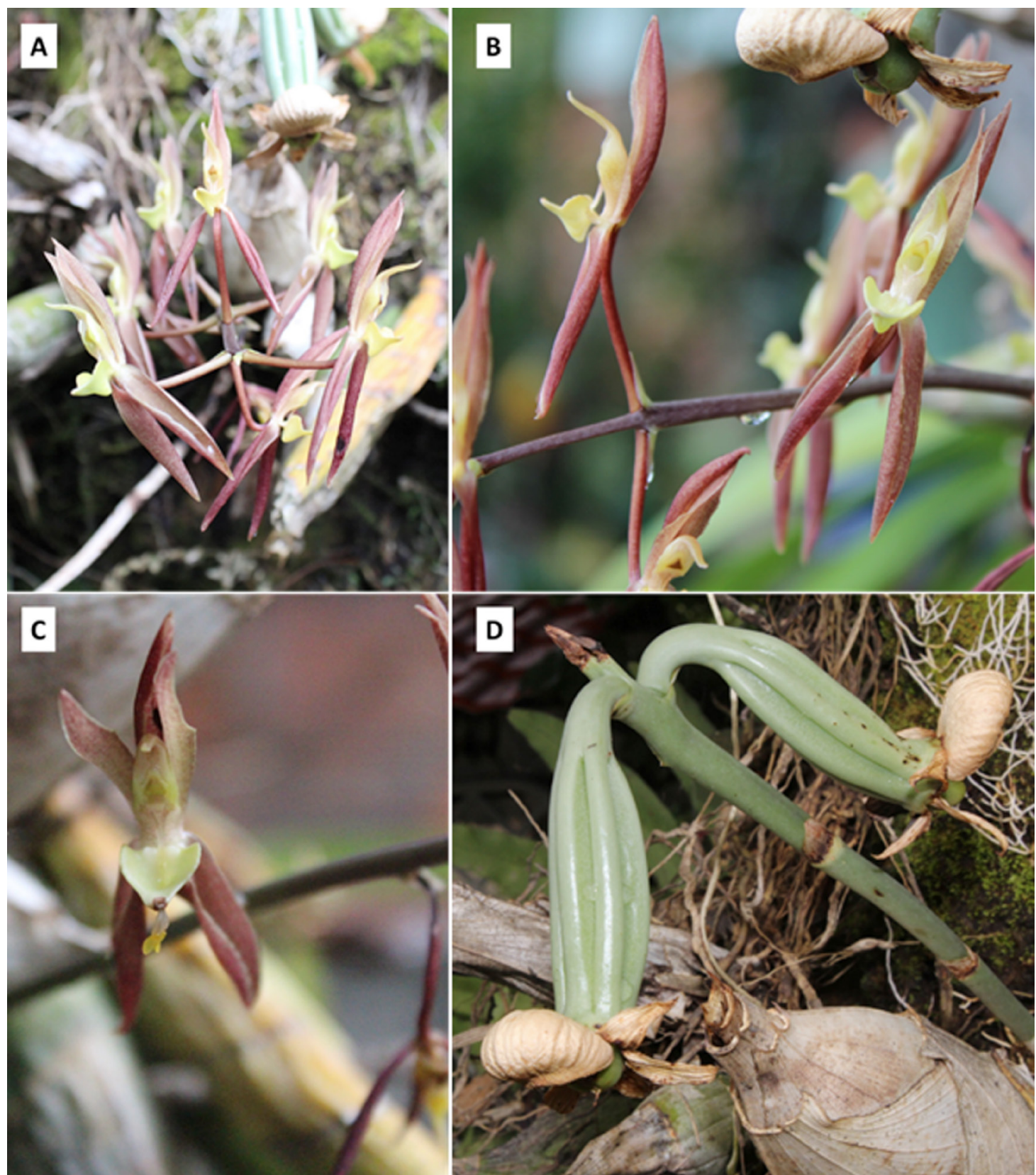

Figure 2. Catasetum lucisuareziae M. Bonilla, J. Mosquera \& Benelli. A. Inflorescence. B. Male flower, lateral view. C. Male flower, frontal view. D. Imature fruit. Illustration by M. M. Bonilla-M.

In addition, $C$. lucisuareziae has a lobed labellum with two subglobulares calli ( $v s$. entire with a single callus), and the apex straight basck ( $v s$. arched and slightly curved) (Table 1).

Catasetum lucisuareziae can also be compared to $C$. bicolor, which is recorded for Colombia in the bioregion of the Atlantic and the Middle Magdalena valley between the Cordillera Central (CC) and the Cordillera Oriental (CO), on the western flank. However, it was not registered from the eastern flank of the $\mathrm{CO}$ or the bioregion of the Orinoco (Bonilla et al. 2013b, Ortiz 2015). Nevertheless, the 3-lobed labellum 


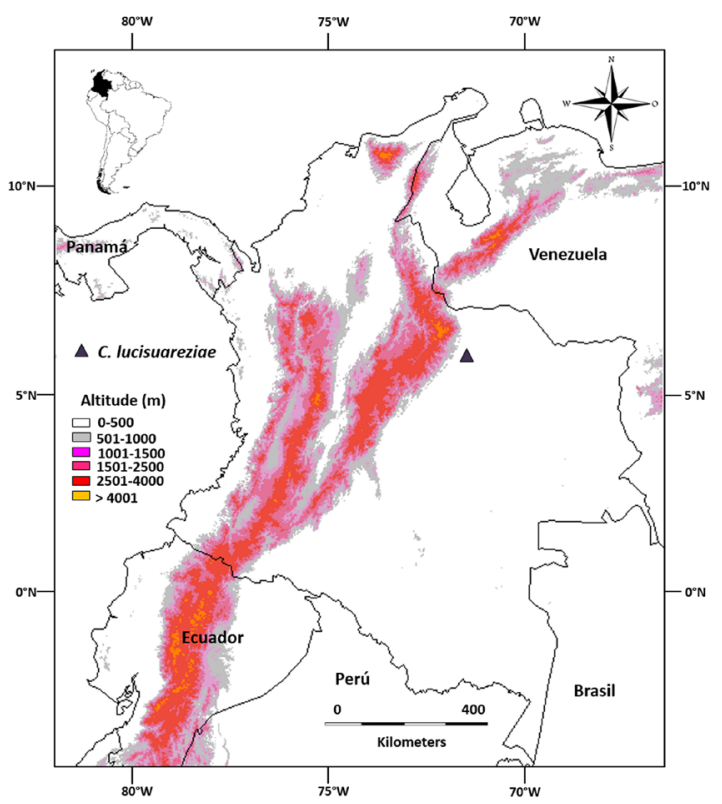

Figure 3. Distribution of $C$. lucisuareziae in Colombia.

Illustration by M. M. Bonilla-M.

with elliptical lobes distinguishes this species, whereas in C. bicolor the lip is 5-lobed with three lobes at the apex (the triangular central lobe triangular and the other two linear), and the laterals lobes are upright. Moreover, instead of the two subglobular calli at the base of the lip, C. bicolor presents two ligules, one on each side lobe.

The new species and $C$. bicolor can also be compared to $C$. boyi Mansf. However, while C. bicolor is distributed from Panama to Venezuela, C. boyi is exclusively known from Brazil (Govaerts et al. 2015), in regions quite distant from the area of occurrence of $C$. lucisuareziae in the Colombian Orinoquia. The main morphologic differences between the species of this complex can be by observed in Figure 4, where the flowers of the four species related to C. lucisuareziae are shown. Catasetum lucisuareziae differs from C. boyi by its elliptic oblong, $2.9 \mathrm{~cm}$ long dorsal sepal versus elliptic-lanceolate, 2.5 $\mathrm{cm}$ long. The lateral lobes of the labellum are suberect in C. lucisuareziae, vs. distinctly erect in C. boyi (Fig. 5); in the first species they have slightly undulate margins and the mid-lobe is smooth, whilst in the latter the margins of the lateral lobes and the midlobe are strongly undulate; in the central portion, the labellum of $C$. lucisuareziae is $9 \mathrm{~mm}$ depth, while in $C$. boyi it is only $3 \mathrm{~mm}$ depth; the calli of the lip are subglobular in $C$. lucisuareziae, but they are triangular and obliquely erect in $C$. boyi.

AcKNowledgements. We thank Álvaro Velázquez Suárez for providing the specimens used for this study. To the anonymous reviewers who have provided helpful comments. APB thanks the "Coordenadoria de Aperfeiçoamento de Pessoal de Nivel Superior - CAPES' for the fellowship awarded to the last author.

\section{LiterATURE CITED}

Betancur, J., Sarmiento, H., Toro-González, L. \& Valencia, J. (2015) Plan para el estudio y la conservación de orquídeas en Colombia. Universidad Nacional de Colombia, Facultad de Ciencias, Instituto de Ciencias Naturales y Ministerio de Ambiente. 336 p.

TABLE 1. Comparison of floral details between Catasetum lucisuareziae and its closest relatives.

\begin{tabular}{|c|c|c|c|c|}
\hline & Catasetum lucisuareziae & C. rectangulare & C. callosum & C. boyi \\
\hline Bract & Oval-lanceolate & Lanceolate & Oblong & Ovate-lanceolate \\
\hline Peduncle & $30 \times 4-5 \mathrm{~mm}$ & $25-30 \times 3.5-4 \mathrm{~mm}$ & $25-30 \times 3.5-4 \mathrm{~mm}$ & $40 \times 2-3 \mathrm{~mm}$ \\
\hline Dorsal sepal & $29 \times 7 \mathrm{~mm}$ & $25-31 \times 5-6 \mathrm{~mm}$ & $25-42 \times 6-8 \mathrm{~mm}$ & $25 \times 8 \mathrm{~mm}$ \\
\hline Lateral sepal & $30 \times 7 \mathrm{~mm}$, reflexed & $23-27 \times 5-7 \mathrm{~mm}$, falcate & $\begin{array}{l}24-4 \times 8-9 \mathrm{~mm} \text {, reflexed } \\
\text { somewhat oblique }\end{array}$ & $\begin{array}{l}38 \times 4 \mathrm{~mm} \text {, } \\
\text { reflexed }\end{array}$ \\
\hline Petals & $26 \times 5 \mathrm{~mm}$, elliptic & $\begin{array}{l}22-25 \times 5-7 \mathrm{~mm} \text {, linear } \\
\text { to oblong-lanceolate }\end{array}$ & $\begin{array}{l}22-38 \times 5-55 \mathrm{~mm} \text {, linear } \\
\text { to oblong-lanceolate }\end{array}$ & $25 \times 8 \mathrm{~mm}$ \\
\hline Labellum & $\begin{array}{l}6 \mathrm{~mm} \text { long } \times 10 \mathrm{~mm} \text { wide } \\
\times 9 \mathrm{~mm} \text { deep }\end{array}$ & $\begin{array}{l}17 \mathrm{~mm} \text { long } \times 6 \mathrm{~mm} \text { wide } \\
\times 4 \mathrm{~mm} \text { deep }\end{array}$ & $\begin{array}{l}13-21 \mathrm{~mm} \text { long } \times 8-10 \\
\mathrm{~mm} \text { wide } \times 5-6 \mathrm{~mm} \text { deep }\end{array}$ & $\begin{array}{l}6 \mathrm{~mm} \text { long } \times \text { ca } 4 \mathrm{~mm} \\
\text { wide } \times \text { ca } 3 \mathrm{~mm} \text { deep }\end{array}$ \\
\hline Labellum ornament & $\begin{array}{l}\text { Trilobed, lateral lobes } \\
\text { with denticulate margin, } \\
\text { slightly elliptical margin } \\
\text { entire central lobe and } \\
\text { two subglobular calluses, } \\
\text { smooth, basal }\end{array}$ & $\begin{array}{l}\text { Entire, rectangular, } \\
\text { margin entire or } \\
\text { denticulate, triangular } \\
\text { apex, callus I dispersed } \\
\text { in the base with a central } \\
\text { uplift. }\end{array}$ & $\begin{array}{l}\text { Entire, lanceolate, ovate } \\
\text { or slightly pandurate, } \\
\text { smooth or irregularly } \\
\text { toothed margin, acute } \\
\text { apex, central callus and a } \\
\text { lifting apiculate }\end{array}$ & $\begin{array}{l}\text { Trilobed, lateral lobes } \\
\text { with filiform margin, } \\
\text { semiovate margin filiform } \\
\text { central lobe and two } \\
\text { erect triangular calluses, } \\
\text { basal }\end{array}$ \\
\hline Staminate Column & Erect, $18 \times 3-4 \mathrm{~mm}$ & Arched, $14 \times 7 \mathrm{~mm}$ & Slightly curved, $12 \times 5-6 \mathrm{~mm}$ & Erect, $20 \times 4 \mathrm{~mm}$ \\
\hline
\end{tabular}



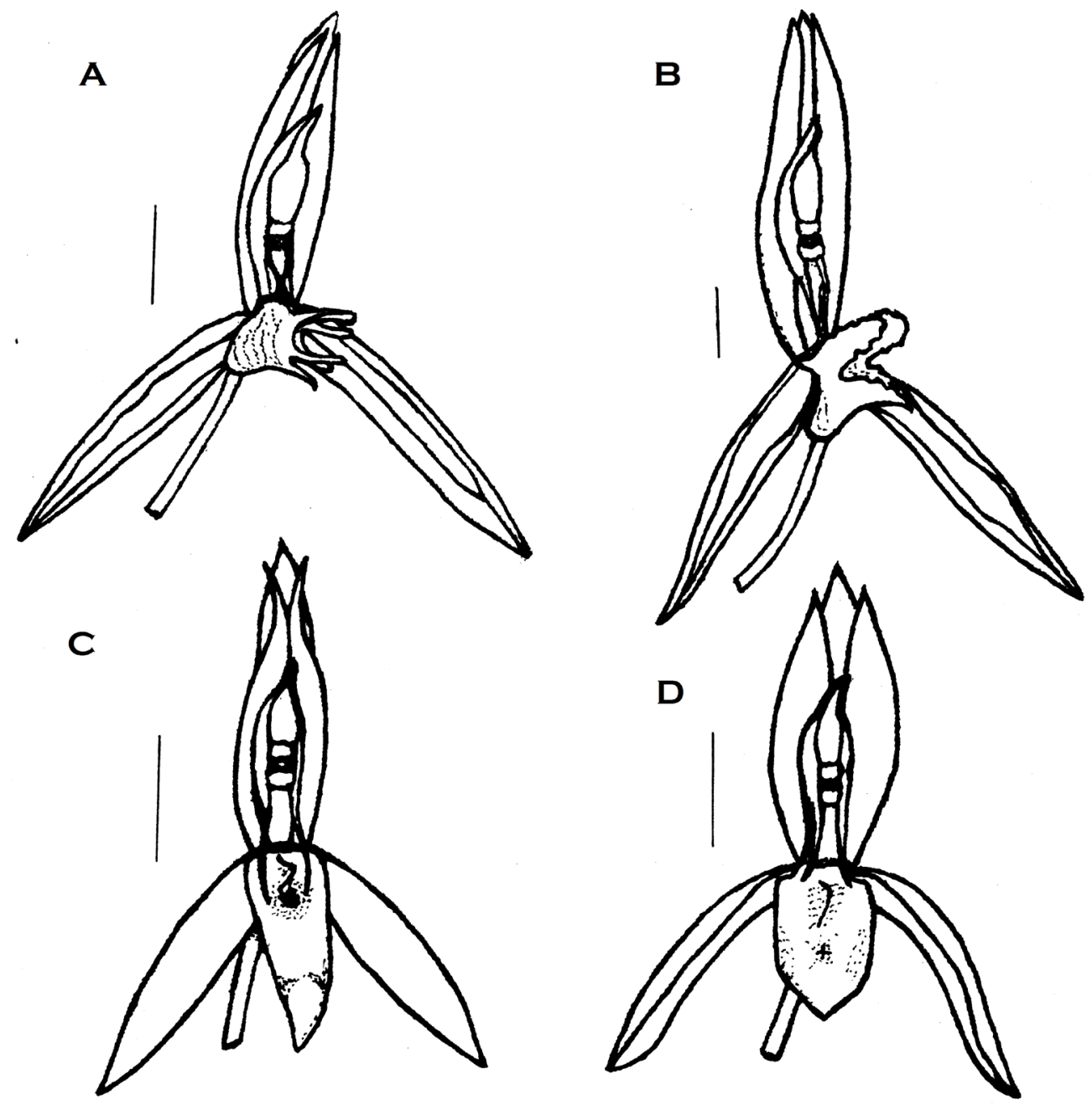

Figure 4. Comparison of the flowers between A. Catasetum bicolor, B. C. boyi, C. C. callosum and D. C. retangulare. Illustration by M. M. Bonilla-M. and A. Petini-Benelli.

Bonilla, M., Mosquera, J. \& Otero J. (2013a) Biogeografía y

Taxonomía de Catasetum, p. 252. In: Cardona, M.A.Q.,

Tamayo, B.V. \& Andrade, H. (eds.), (Annals) Memorias

VII Congreso Colombiano de Botánica, Aug. 6-10,

2013. Ibagué, Colombia, Universidad del Tolima \& Asociación Colombiana de Botánica.

Bonilla, M., Mosquera, J. \& Otero, J. (2013b). Distribución espacial de la orquideoflora del Meta, p. 51. In: Cardona, M.A.Q., Tamayo, B.V. \& Andrade, H. (eds.), (Annals) Memorias VII Congreso Colombiano de Botánica, Aug. 6-10, 2013. Ibagué, Colombia, Universidad del Tolima \& Asociación Colombiana de Botánica.

Bonilla, M., Yepes, D. \& Otero, J. T. (2014). Diversidad y distribución de Catasetum rectangulare G.F.Carr (Orchidaceae: Catasetinae). Orquideología, 31(1), 15-25.
Carr, G. (2006). Catasetum rectangulare. Orchid Review, 114(1267), 32-33.

Chase, M. W., Cameron, K., Freudenstein, J., Pridgeon, A., Salazar, G., van den Berg, C. \& Schuiteman, A. (2015). An updated classification of Orchidaceae. Botanical Journal of the Linnean Society, 177, 151-174.

Govaërts, R., Bernet, P., Kratochvil, K., Gerlach, G., Carr, G. F., Alrich, P., Pridgeon, A. M., Pfahl, J., Campacci, M. A., Baptista, D. H., Tigges, H., Shaw, J., Cribb, P., George, A., Kreuz, K. \& Wood, J. (2014). World Checklist of Orchidaceae. Facilitated by the Royal Botanic Gardens, Kew. Recovered from http://apps. kew.org/wcsp/ [Accessed 1 Feb 2015].

IUCN Standards and Petitions Subcommittee. (2014). Guidelines for Using the IUCN Red List Categories 


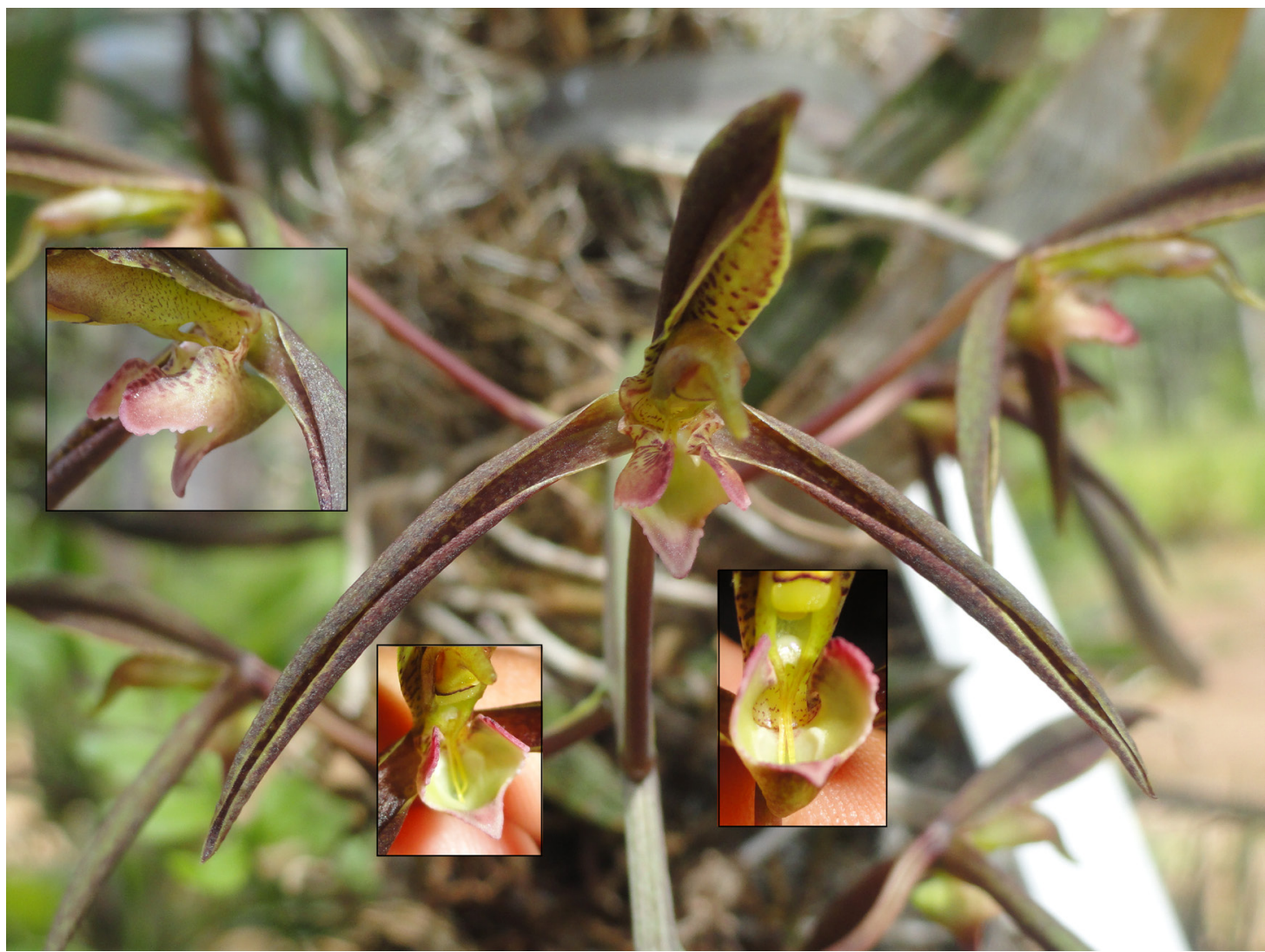

Figure 5. Catasetum boyi, frontal and lateral view, with closeups of the labellum. Photography by A. Petini-Benelli.

and Criteria. Version 11. Prepared by the Standards and Petitions Subcommittee. Recovered from: http:// www.iucnredlist.org/documents/RedListGuidelines.pdf [Accesed: February 2014].

Jiménez, C. (2011). Orquídeas del Meta. Meta-Colombia (CD Edition). ISBN: 978-958-44-9677-5.

Ortiz, P. \& Uribe, C. (2007). Galería de Orquídeas de Colombia. Bogotá, Asociación Bogotana de Orquideología (CD Edición).

Ortiz, P. \& Uribe, C. (2014). Orquídeas, tesoro de Colombia $(A-D)$. Bogotá, Colombia: Da Vinci Publicidad y Medios.

Ortiz, P. (2015). Catasetum. In: Bernal, R., Grasdstein, S. \& Celis, M. (eds). Catálogo de plantas y líquenes de Colombia. Bogotá, Instituto de Ciencias Naturales de Colombia. Available at: http://catalogoplantascolombia. unal.edu.co

Romero, G. A. \& Jenny, R. (1993). Contributions toward a monograph of Catasetum (Catasetinae, Orchidaceae)
I: A checklist of species, varieties, and natural hybrids. Harvard Papers in Botany, 4, 59-84.

Romero, G. A. (2009). Subtribe Catasetinae. Pp 11-12 in: Pridgeon, A.M., Cribb, P.J. \& Chase, M.W. (eds). Genera orchidacearum 5, Epidendroideae (part two). Orford, Oxford University Press.

Romero, G. A. (2012). Las flores unisexuales y dimórficas de Catasetum Rich. (Orchidaceae). Herbario CICY, 4, 32-36.

Sarmiento, J. (2007). La familia Orchidaceae en Colombia. Actualidades biológicas, 29 (Supl. 1), 21-84.

Senghas, K. (1990) Subtribe Catasetinae. Pp. 1583-1601, 2765-2768 in: Brieger, F.G., Maatsch, R. \& Senghas, K. (eds). Rudolf Schlechter's Die Orchideen 1. 3th. Ed. Berlin, Paul Parey,.

Usma, J. S. \& Trujillo, F. (eds) (2011). Biodiversidad del Casanare: Ecosistemas Estratégicos del Departamento. Bogotá, Gobernación de Casanare - WWF Colombia. 
LANKESTERIANA 